\title{
Evaluation of anti-inflammatory and anti-angiogenesis effects of naloxone in the rat air pouch model of inflammation
}

Tahereh Eteraf-Oskouei ${ }^{1}$, Atefeh Zabiholahi ${ }^{2}$, Moslem Najafi ${ }^{3}$, Bohlool Habibi-Asl ${ }^{3}$

${ }^{1} \mathrm{PhD}$ of Pharmacology, Associate Professor, Department of Pharmacology \& Toxicology, Faculty of Pharmacy, Tabriz University of Medical Sciences, Tabriz, Iran

${ }^{2}$ PharmD, Department of Pharmacology \& Toxicology, Faculty of Pharmacy, Tabriz University of Medical Sciences, Tabriz, Iran

${ }^{3} \mathrm{PhD}$ of Pharmacology, Professor, Department of Pharmacology \& Toxicology, Faculty of Pharmacy, Tabriz University of Medical Sciences, Tabriz, Iran

Type of article: Original

\begin{abstract}
Background and objective: There is increasing evidence that the nervous system is in two-way interaction with the immune system. To study the relationship between the opioid and immune systems, the anti-inflammatory effect of naloxone - an opioid receptor antagonist - in the air pouch model as an animal model of rheumatoid arthritis was studied.

Methods: Sterile air (20 and $10 \mathrm{ml}$ ) was subcutaneously injected into the back of the animals on days 1 and 3, respectively. On the $6^{\text {th }}$ day, carrageenan was injected into the pouch. Normal saline and different doses of naloxone were injected immediately, as well as 24 and 48 hours after carrageenan in the control and treatment groups, respectively. After 72 hours, granulation tissue was opened, the pouch fluid was collected to determine the volume of exudates, the concentration of Vascular Endothelial Growth Factor (VEGF) and Interleukin 1 beta (IL-1 $\beta$ ) and count of leukocyte. Granulation tissue was extruded and weighed. To assay the angiogenesis, the granulation tissue was homogenized and centrifuged, and the supernatant was filtered by a $0.22 \mu$ filter. Hemoglobin concentration was determined by the hemoglobin kit.

Results: Naloxone clearly reduced leukocyte accumulation ( $p<0.01)$, exudate volume $(p<0.001)$, granulation tissue weight $(\mathrm{p}<0.01)$, and amount of angiogenesis in the granulation tissue $(\mathrm{p}<0.001)$. In addition, VEGF and IL-1 $\beta$ levels were decreased significantly $(p<0.01)$ and $(p<0.001)$, respectively.

Conclusion: Naloxone can reduce inflammatory and angiogenesis parameters in an air pouch inflammatory model. The anti-inflammatory effect is probably related to inhibition of leukocyte accumulation due to decreased concentration of inflammatory cytokines in exudates.
\end{abstract}

Keywords: Naloxone, Inflammation, Angiogenesis, Vascular Endothelial Growth Factor, Interleukin-1

\section{Abbreviations / Acronyms: \\ IL-1及: Interleukin 1 beta; NO: Nitric Oxide; PBS: Phosphate Buffer Solution; RA: Rheumatoid Arthritis; RCF: Relative Centrifugal Force; VEGF: Vascular Endothelial Growth Factor}

\section{Introduction}

The connection between the nervous system and the immune system has attracted researchers' attention for many years, and several articles have been published in this area (1). The two systems have the same function at the cellular level. The immune system cells, like the nervous system, have two-way communication, and exchange information between each other. Different proteins that were considered to be unique to the nervous system have recently been found in the immune system (2). Immune system cells independently produce neuropeptides and

\section{Corresponding author:}

Associate Professor Dr. Tahereh Eteraf-Oskouei. Department of Pharmacology \& Toxicology, Faculty of Pharmacy, Tabriz University of Medical Sciences, Tabriz, Iran.

Tel: +98-4133372250, Fax: +98-4133344798, E-mail: eteraf_t@yahoo.com

Received: August 07, 2019, Accepted: January 14, 2020, Published: June 2020

iThenticate screening: January 04, 2020, English editing: March 01, 2020, Quality control: May 04, 2020

This article has been reviewed / commented by four experts

Ethics approval: Tabriz University of Medical Sciences, Tabriz-Iran (Ref.: 3836).

(C) 2020 The Authors. This is an open access article under the terms of the Creative Commons Attribution-NonCommercialNoDerivs License, which permits use and distribution in any medium, provided the original work is properly cited, the use is non-commercial and no modifications or adaptations are made. 
neurotransmitters, for example, lymphocytes produce peptide hormones, and neurotransmitters such as acetylcholine, serotonin, and endorphins (3). Research has also indicated that there are receptors for neuropeptides on the surface of immune system cells $(4,5)$. In other words, the immune system acts through chemical mediators like a sensory organ for the nervous system (6). In recent years, our research has been focused on the axis of this two-way communication and in the case of oxytocin, adrenergic and serotonergic systems, have yielded interesting results (7-9). Considering the role of opioids and their receptors in the immune system and in chronic inflammatory conditions such as rheumatoid arthritis $(10,11)$, this study aimed to investigate the role of the opioid system in peripheral inflammation and angiogenesis using naloxone - an opioid receptor antagonist - in the air pouch inflammatory model in rats. The air pouch model is developed by subcutaneous injection of sterile air into the back of the rat. After the air is injected, a cavity is formed that consists of some cells, including primary macrophages and fibroblasts. After six days, this structure is similar to the joint structure, and the inflammation examined in this model is a mimic of joint inflammation (12). Angiogenesis and chronic inflammation in pathological conditions, including rheumatoid arthritis, have interactive effects on each other, and in most cases, angiogenesis is effective in the progression of chronic inflammation, while chronic inflammation also provides conditions for the progression of angiogenesis (13). Considering this, inhibition of angiogenesis is an important therapeutic target in chronic inflammatory diseases like rheumatoid arthritis (RA) (14). In this study, the effects of naloxone on inflammatory and angiogenesis parameters, Vascular Endothelial Growth Factor (VEGF) and Interleukin 1 beta (IL-1 $\beta$ ) concentrations in exudate fluid were investigated.

\section{Material and Methods}

\subsection{Chemicals}

The following chemicals were obtained: Naloxone (Tolid Darou, Iran), Carrageenan (Sigma, Germany), Ethylenediaminetetraacetic acid (Merck, Germany), hemoglobin kit and Drabkin reagent (ZistChem Diagnostics, Iran), VEGF kit (Hangzhou Eastbiopharm, USA), Ethylene Diamine Tetra Acetic Acid, and IL-1 $\beta$ kit (BosterBio USA). All other chemicals were of the highest grade commercially available.

\subsection{Animal}

Male Wistar rats (200 -250 g, Pasture Institute, Tehran, Iran) were used in 5 groups of 6 animals. The animals were kept at the animal house of the Faculty of Pharmacy affiliated with Tabriz University of Medical Sciences, Tabriz, Iran and acclimatized to the laboratory environment for at least $1 \mathrm{~h}$ before the experiments, and used only once throughout the study. The animals had free access to water and food, and they were kept under standard conditions at $22 \pm 3{ }^{\circ} \mathrm{C}$ and 12 hours of light and 12 hours of darkness in a light cycle.

\subsection{Research ethics}

The present study was performed in accordance with the Guide for the Care and Use of Laboratory Animals of Tabriz University of Medical Sciences, Tabriz-Iran (NO. 3836).

\subsection{Creation of air pouch model of inflammation by carrageenan in rats}

After light anesthesia, the hair on the back of the animals was shaved, the injection site was disinfected by ethanol $70 \%$, and then $20 \mathrm{ml}$ of sterile air was subcutaneously injected into the back of the rats. To minimize tissue damage during injection, a fine needle $(25 \mathrm{G})$ was attached to the syringe. Three days later, again, after anesthetizing the animal, $10 \mathrm{ml}$ of sterile air was injected into the same region. On the sixth day after the first injection, $2 \mathrm{ml}$ of $2 \%$ carrageenan was injected into the cavity on the back of the anesthetized animal (Figure 1). To prevent possible infection, the suspension of carrageenan was autoclaved at $121^{\circ} \mathrm{C}$ for 15 minutes (12). In the control group, normal saline and in the test groups, naloxone (100,200, 400 and $800 \mu \mathrm{g} /$ pouch) was injected into the pouch of each rat at a dose of $1 \mathrm{ml}$ just before carrageenan injection and then for 2 consecutive days. Three days after the last injection, the rats were euthanized and after shaving the entire hair of the animal's back area, the skin surface on the pouch was carefully disinfected by $70 \%$ ethanol. After drying the site, the pouch was gently opened with sharp scissors, and the inflammatory exudate was syringed and then its volume was measured. Exudate accumulation following carrageenan injection is due to the secretion of inflammatory mediators such as prostaglandins (15). To prevent clotting, some of the exudates were poured into the test tube containing a small amount of Ethylene Diamine Tetra Acetic Acid (EDTA; Merck) and mixed well. Then the exudate was diluted with phosphate buffer solution (PBS), and the number of white blood cells was counted using a neobar lam (Boec; Germany) under a light microscope (Olympus; Japan). Following the injection of carrageenan and induction of inflammation, granulation tissue formed around the pouch, which was carefully separated from the animal in order to weigh it. For this purpose, after collecting all the exudates inside the pouch, the outer skin was cut, and the pouch was removed from the surrounding tissues and weighed (12). 


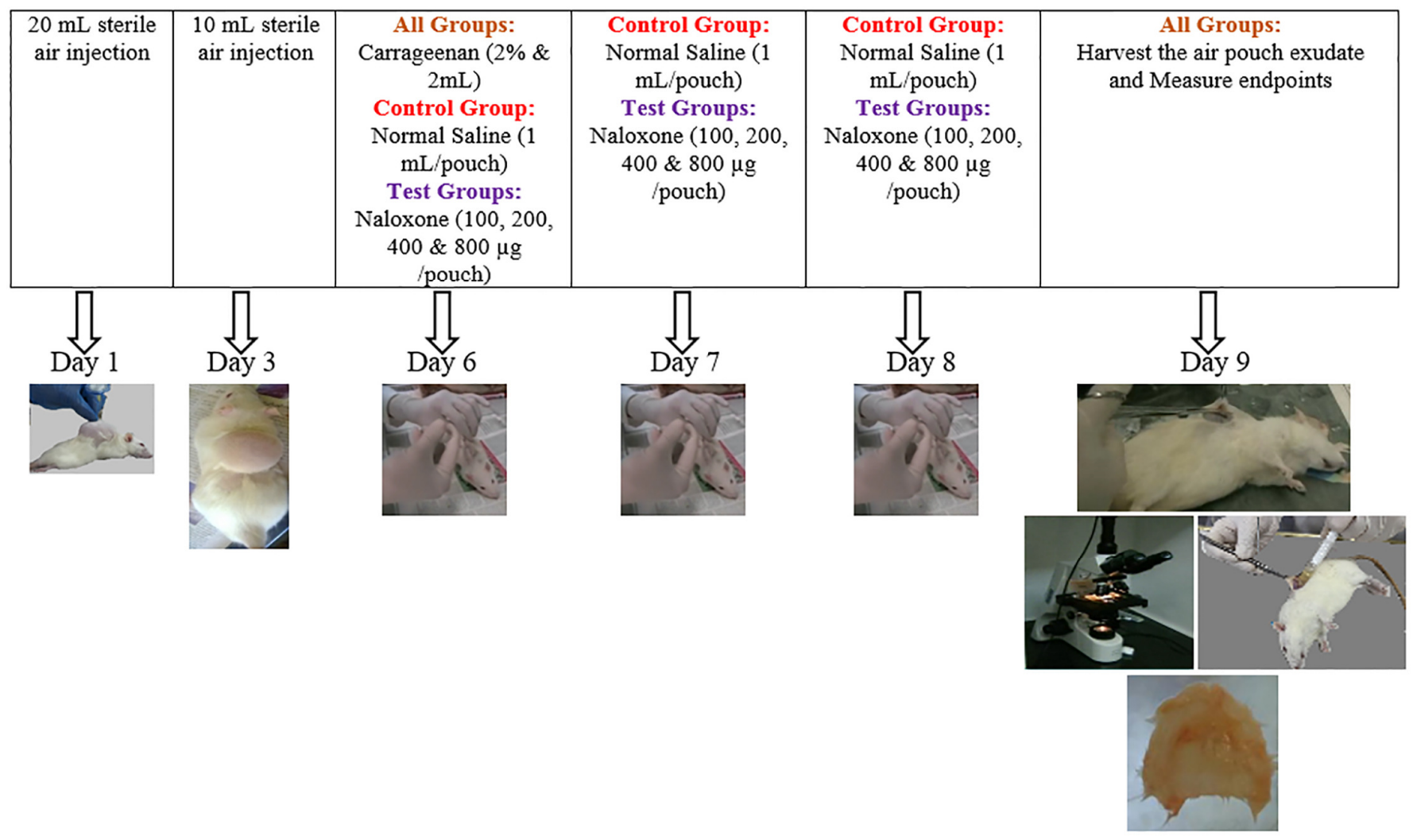

Figure 1. Schematic of the rat air-pouch in vivo model.

\subsection{Determination of the amount of IL-1 $\beta$ and VEGF in exudates}

Three days after induction of inflammation, secreted exudates were collected and transferred to test tubes. Then they were centrifuged (1000 rpm for 10 minutes) with refrigerated centrifuge (Eppendorf Centrifuge 5810R; Germany). The supernatant was stored in the freezer to determine the amount of IL-1 $\beta$ and VEGF using commercial ELISA kits, according to the manufacturer's instructions.

\subsection{Angiogenesis investigation in granulation tissue}

For angiogenesis, granulation tissue was washed gently in PBS and then cut into small pieces. Drobkin solution prepared from the hemoglobin kit, was added and homogenized for 4 minutes at 15,000 and in a $4{ }^{\circ} \mathrm{C}$ ice bed by a homogenizer (Heidolph; Germany). Homogeneous tissue was then centrifuged (Eppendorf Centrifuge 5810R; Germany) for 30 minutes at $4{ }^{\circ} \mathrm{C}$ and RCF 1000 . The supernatant was filtered by $0.22 \mu$ filter (Millipore), and the amount of hemoglobin in supernatant was measured as an angiogenesis index using standard hemoglobin kits and spectrophotometer apparatus (Shimadzu UV-1800; Japan) at $540 \mathrm{~nm}$ wavelength (9).

\subsection{Statistical Analysis}

Data are shown as mean \pm SEM. The data were analyzed by one-way ANOVA and by LSD post hoc test using the SPSS ver.17 software. Any difference between the groups with the level of $\mathrm{P}<0.05$ was considered significant.

\section{Results}

\subsection{Effect of naloxone on the cellular infiltration, exudation and granulation tissue weight}

Three days following administration of different doses of naloxone, inflammatory parameters including leukocytes number, volume of exudate and granulation tissue weight were measured. Analysis of the inhibitory profiles using the investigated doses $(100,200$ and $400 \mu \mathrm{g} /$ pouch) of naloxone indicated that significant inhibition of leukocyte migration occurred [by 55.8\% $(\mathrm{p}<0.01), 55.6 \%(\mathrm{p}<0.01)$ and $74.7 \%(\mathrm{p}<0.001)$ for each dose, respectively] (Figure $2 \mathrm{~A})$. The results showed that 72 hours after inflammation induction, the amount of exudate in the control group was $7.23 \pm 0.3 \mathrm{ml}$. Only $400 \mu \mathrm{g}$ with a significant level of $\mathrm{p}<0.001$ could reduce the volume of exudates compared to the control group (by 15.6\%; Figure 2B). The granulation tissue formed around the pouch after collecting the exudate was isolated from the animal and then weighed. Naloxone showed a significant difference in terms of weight loss in the granulation tissue $(\mathrm{p}<0.01)$. Although naloxone at doses of 100 and $800 \mu \mathrm{g}$ did not change the weight of the 
granulation tissue more than that of the control group (4.6 $\pm 0.1 \mathrm{~g}$ ), the doses of 200 and $400 \mu \mathrm{g}$ decreased its weight [by $17.4 \%$ and $21.7 \%(\mathrm{p}<0.05)$ respectively], Figure $2 \mathrm{C})$.
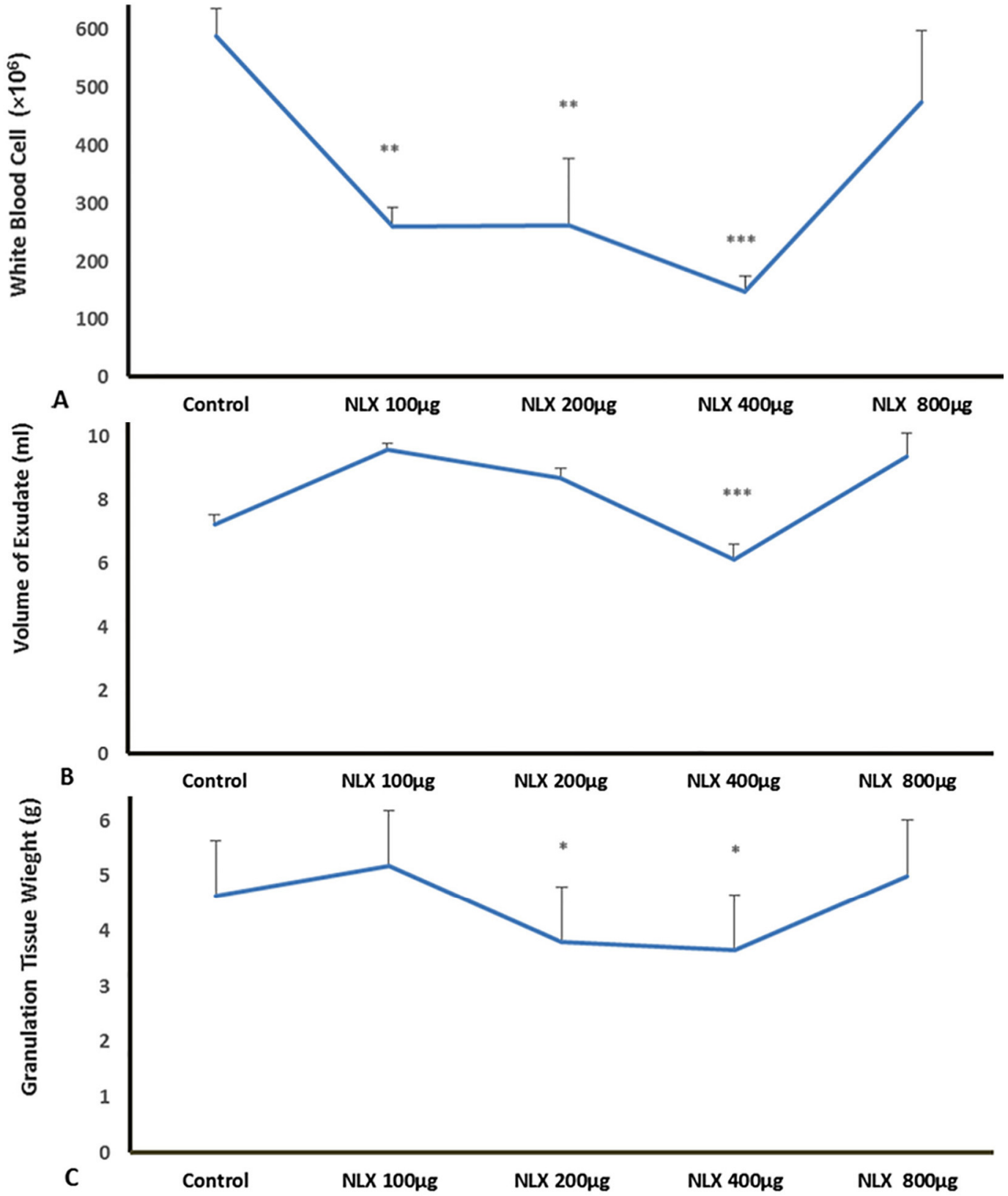

Figure 2. Effect of naloxone on leukocyte accumulation (A), exudate volume (B) and granulation tissue weight $(\mathrm{C})$. Asterisks indicate significant difference when compared to the control. ${ }^{*} \mathrm{p}<0.05,{ }^{* *} \mathrm{p}<0.01,{ }^{*} \mathrm{p}<0.001$ based on ANOVA; NLX $=$ Naloxone.

\subsection{Effect of naloxone on angiogenesis 3 days after induction of inflammation}

Three days after injection of carrageenan and induction of inflammation, the rat was euthanized, and the granulation tissue formed around the pouch was isolated. After homogenization and centrifugation of the tissue, the supernatant was filtered by a $0.22 \mu$ filter (Sigma, Germany), and the amount of hemoglobin in the tissue was determined as an angiogenesis index by the hemoglobin kit. The anti-angiogenesis effects of naloxone by doses $(100,200,400 \& 800$ $\mu \mathrm{g} /$ pouch) on the hemoglobin contents as an angiogenesis marker were $14 \%, 58 \%, 25 \%$ and $60 \%$, respectively. Naloxone ( $200 \& 800 \mu \mathrm{g} /$ pouch) produced higher reduction in hemoglobin levels when compared to the control rats $(\mathrm{P}<0.001$; Figure 3). 


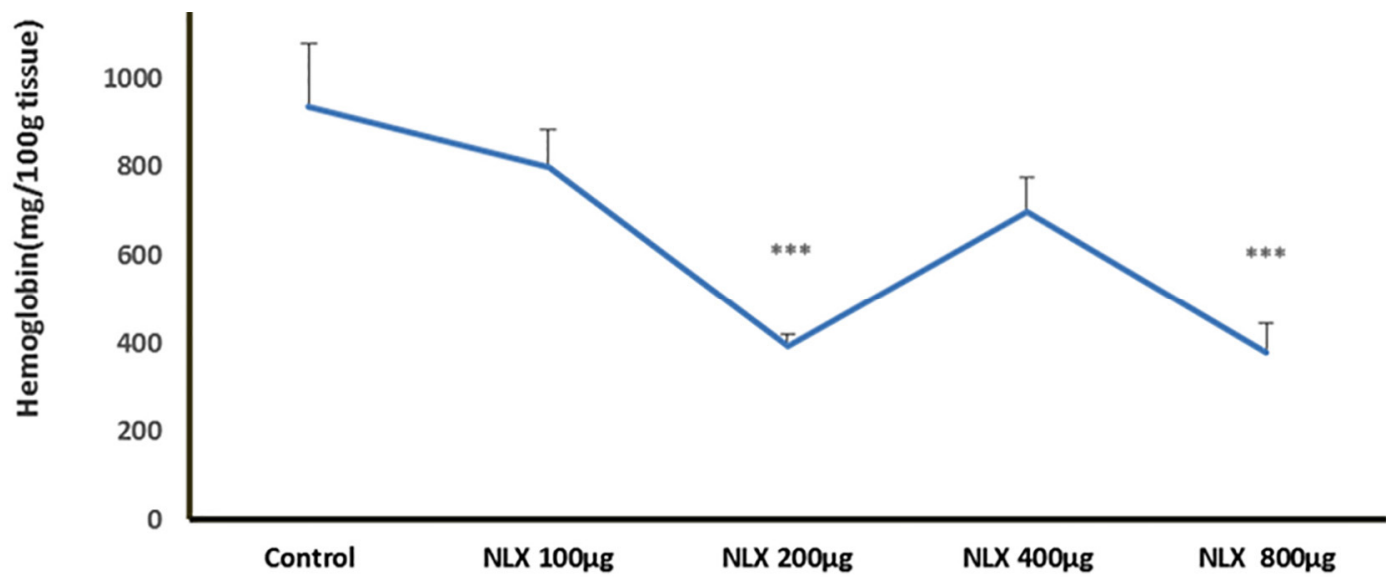

Figure 3. Evaluation of the effect of naloxone on angiogenesis of granulation tissue $(n=6)$. Values are mean \pm SEM shown by vertical bars. Asterisks indicate significant change from control. $* * * \mathrm{p}<0.001$ based on ANOVA; NLX= Naloxone.

\subsection{Effect of naloxone on VEGF and IL-1B of exudates 3 days after induction of inflammation}

Three days after induction of inflammation, the rat was euthanized, inflammatory exudates were collected, and after centrifugation, the concentration of VEGF and IL-1 $\beta$ in the supernatant-lacking inflammatory exudate cells was measured by the ELISA kit. Figure 4 depicts the dose-dependent variations in VEGF and IL-1 $\beta$ concentrations in response to increasing naloxone concentrations. Intra pouch injection of naloxone (100, 200, 400 and $800 \mu \mathrm{g} / \mathrm{pouch})$ again decreased VEGF levels by $45.1 \%, 38.2 \%, 35.6 \%$ and $42.8 \%$, respectively; (Figure 4A). Similarly, significant reduction in IL-1 $\beta$ concentrations was also achieved following administration of naloxone (100, 200 and 800 $\mu \mathrm{g} /$ pouch) by $38.8 \%, 31.2 \%$ and $57.2 \%$ respectively; (Figure $4 \mathrm{~B}$ ).

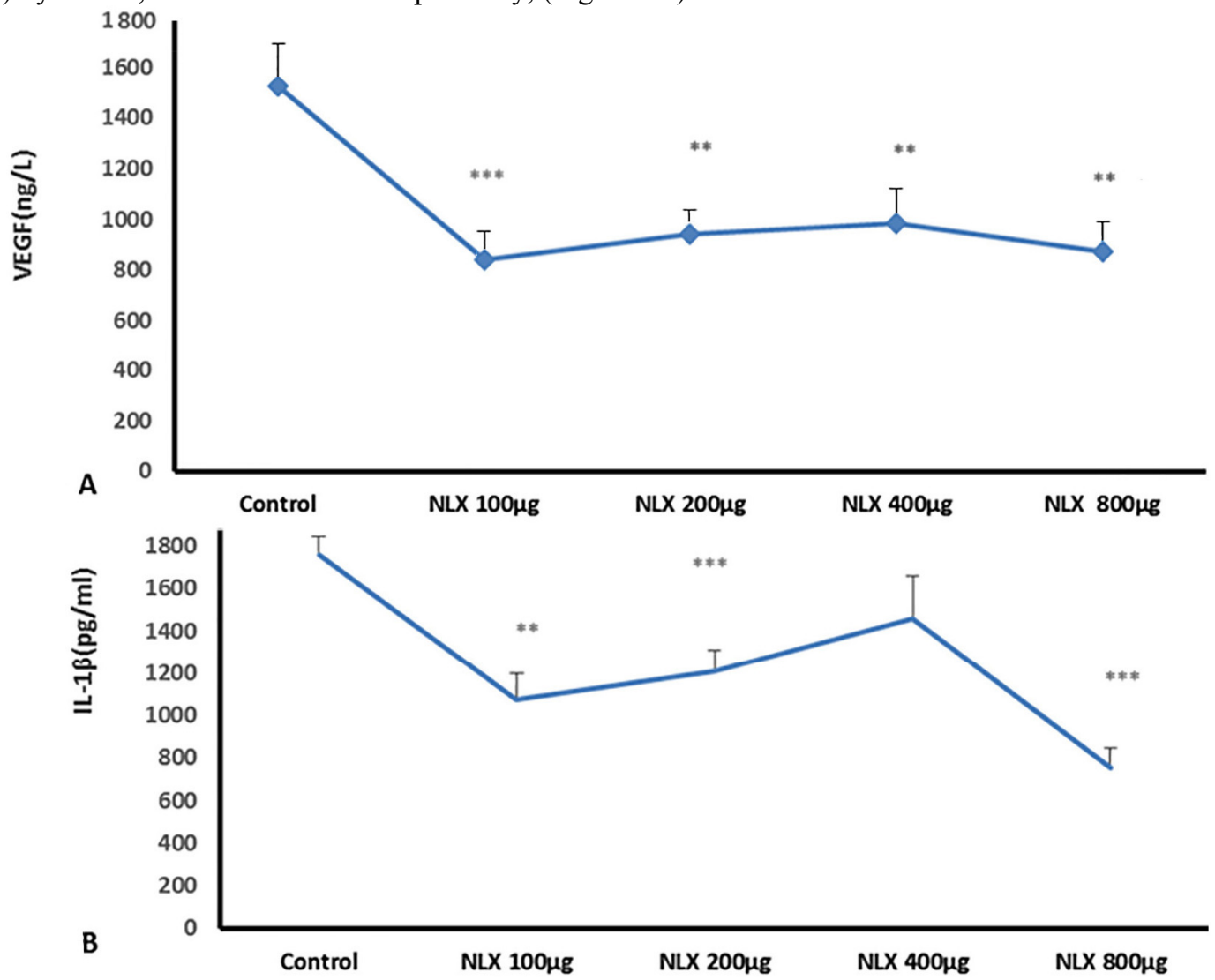

Figure 4. The effect of naloxone on the amount of VEGF (A) and IL-1 $\beta$ (B) in the inflammatory exudates $(n=6)$. Values are the mean \pm SEM shown by vertical bars. Asterisks indicate significant change from control. $* * \mathrm{p}<0.01, * * * \mathrm{p}<0.001$ based on ANOVA; NLX= Naloxone. 


\section{Discussion}

In the present work, the anti-inflammatory effects of naloxone as an opioid receptor antagonist were investigated in an air pouch inflammatory model. To elucidate the mechanism of anti-inflammatory and anti-angiogenesis effects of naloxone, the concentrations of two candidate proinflammatory mediators were measured. Based on the study results, intra pouch injection of naloxone significantly reduced leukocyte accumulation. Consistent with our results, Cornwell et al. found that the numbers of circulating immune cells were significantly increased with chronic morphine administration (16). Evidence suggests that IL-1 family cytokines interact with central endogenous opioid transporter systems (17). Also, leukocyte infiltration can be regulated by IL-1 $(18,19)$. Our data confirmed the inhibitory effect of naloxone on IL- $1 \beta$ protein content. It seems that one of the possible mechanisms of naloxone in reducing leukocyte accumulation is decreasing IL-1 $\beta$ production in inflammatory exudates. In another study, Chin et al. (2016) found that naloxone administration reduced the expression of IL-1 $\beta$ gene (20). IL-1 is an inhibitor of proteoglycan synthesis in cartilage, and joint discomfort in people with RA treated with anakinra - a human recombinant IL-1 receptor antagonist - is clearly improved (21).

In this study, naloxone was able to reduce the amount of exudate released into the pouch. Following the injection of carrageenan, vascular permeability increases with the release of mediators such as histamine, serotonin, prostaglandins, leukotrienes and nitric oxide (NO), resulting in inflammatory exudates. In this regard, the role of NO in carrageenan-induced inflammation is particularly significant $(22,23)$. Liu et al. (2002) observed that naloxone increased NO metabolism by the enzyme (24) that could be another possible mechanism for the effect of naloxone to reduce inflammatory exudates.

The formation of granulation tissue is one of the characteristics of chronic inflammation. In addition, the accumulation of fibroblasts and macrophages, collagen synthesis and angiogenesis are important properties of granulation tissue (25). In this work, the weight of granulation tissue showed a significant reduction following naloxone administrations. In line with the results of this study, Smith et al. (2007) observed a reduction in the progression of Crohn's disease due to the weight loss of granulation tissue by low dose of naltrexone (26). Evidence suggests that accumulation of chemokines in synovial tissue contributes to pathogenesis of synovitis (27). Our findings showed that naloxone decreased proinflammatory cytokine concentration including IL-1 $\beta$ and VEGF which cause joint injury by inducing recruitment of white blood cells, exudation and angiogenesis at the site of inflammation in rat model of arthritis. The cytokines derived from macrophages, such as TNF- $\alpha$ and IL-1, play a crucial role in the formation of granulation tissue, so that these cytokines are also called granulomatogenic cytokines (28). The inhibitory effects on the concentration of TNF- $\alpha$ and IL-1 $(29,30)$ can be the proposed mechanisms to reduce the weight of granulation tissue by naloxone.

According to studies, NO produced by macrophages is involved in the formation of granulation tissue (31). Regarding the inhibitory effects of naloxone on NO (24), a low NO concentration may be considered another possible mechanism to reduce granulation weight in this model. Here, we demonstrated that naloxone inhibits angiogenesis in inflammatory granulation tissue, and VEGF and IL1 $\beta$ might play a pivotal role in modulating neovascularization by naloxone. Researchers have identified that VEGF production in granulation tissue depends on NO concentration (32). Considering the inhibitory effect of naloxone on VEGF concentrations in this study, reduction of the weight of granulation tissue following naloxone injection can be justified by this probable mechanism. Angiogenesis is involved in various pathological conditions, including tumor growth, metastasis, and RA, as well as in physiological processes such as organ development, wound healing and reproduction. Angiogenesis is one of the essential processes in the natural physiology of the body, and if the balance between the angiogenesis inducing and inhibiting factors is eliminated, conditions for the occurrence of certain diseases are created (33). VEGF acts as a mitogen for vascular endothelial cells and increases angiogenesis (34). Studies have also demonstrated that VEGF increases vascular permeability (35). Naloxone reduced the concentration of VEGF protein in this study. Perhaps, the possible reason for angiogenesis reduction by naloxone is reduction of VEGF concentration in inflammatory exudates.

VEGF is not only a main angiogenic factor but also a pro-inflammatory mediator in the inflammatory process. According to the results obtained by Croll et al. (2004), VEGF increases the leukocyte turnover by increasing ICAM-1 (36). In addition, some inflammatory mediators such as NO, TNFa, IL-1 and IL-6 regulate VEGF function. (37). Data reported by Lunger et al. (2016) showed an inhibitory effect of naloxone and methyl naltrexone on the VEGF and angiogenesis of female genital tract cells under in vitro fertilization (38). Consistent with our findings, Singleton et al. (2006) also found that methyl naltrexone prevented the proliferation and migration of endothelial 
cells by reducing expression of the gene and transcription of VEGF receptors (39). The active oxygen species produced by active macrophages and neutrophils are angiogenesis-stimulating factors. These oxidative factors enhance the angiogenesis by stimulating production of VEGF (40). Opioid receptors play a role in the activity of macrophages by regulating the production of hydrogen peroxide and protecting against damage from free radicals (41). The anti-inflammatory and anti-angiogenesis effects of naloxone in the present study are possibly associated with its protective effect against free radicals. Inflammation is increasingly recognized as an important mediator of angiogenesis, and it has been reported that uncontrolled angiogenic response is implicated in chronic inflammation. Angiogenesis in RA results in the accumulation of leukocytes and inflammation in the synovium. In addition, synovial inflammation itself enhances endothelial proliferation and angiogenesis (14). On the other hand, chronic inflammation and angiogenesis play an important role in tumor progression and malignancy (42). So that, antiangiogenic drugs can control angiogenesis-related diseases such as cancer (43).

In the present study, it was observed that the pattern of reduction of inflammatory parameters and angiogenesis of naloxone was in the form of a bell-shape, which the highest effect was in the middle dose and higher and lower doses exhibited different anti-inflammatory effects. The same dose-response curve for protective and analgesic effects of opioid antagonists like naloxone has also been reported. Such a dosing curve may be due to the diversity of opioid receptors and their different densities in the immune system (44).

\section{Conclusions}

The findings of the present study revealed that naloxone exhibited anti-inflammatory and anti-angiogenesis effects in the air pouch model of inflammation in male rats. The observed effects are probably related to an inhibitory effect on the VEGF and IL-1 $\beta$ concentration by naloxone. Our results may suggest that pharmacological effects of naloxone could have promising benefits in the treatment of many immune-related diseases, such as RA and cancer. Further studies are recommended to elucidate the precise mechanism of action of naloxone in inflammatory conditions. In addition, our findings should be confirmed by histological examination.

\section{Acknowledgments:}

The content of this paper was extracted from a thesis submitted for fulfillment of a Pharm.D degree (No.3836) in the Faculty of Pharmacy, Tabriz University of Medical Sciences. The authors would like to thank the Drug Applied Research Center, Tabriz University of Medical Sciences for their technical support.

\section{Conflict of Interest:}

There is no conflict of interest to be declared.

\section{Authors' contributions:}

All authors contributed to this project and article equally. All authors read and approved the final manuscript.

\section{References:}

1) Dantzer R. Neuroimmune Interactions: From the Brain to the Immune System and Vice Versa. Physiological reviews. 2018;98(1):477-504. PMid: 29351513 PMCid: PMC5866360

2) Blalock J. The immune system as the sixth sense. Journal of internal medicine. 2005;257(2):126-38. DOI: 10.1111/j.1365-2796.2004.01441.x PMid: 15656872

3) Tayebati SK, El-Assouad D, Ricci A, Amenta F. Immunochemical and immunocytochemical characterization of cholinergic markers in human peripheral blood lymphocytes. Journal of neuroimmunology. 2002;132(1):147-55. DOI: 10.1016/S0165-5728(02)00325-9

4) Pintér E, Pozsgai G, Hajna Z, Helyes Z, Szolcsányi J. Neuropeptide receptors as potential drug targets in the treatment of inflammatory conditions. British journal of clinical pharmacology. 2014;77(1):5-20. DOI: 10.1111/bcp.12097 PMid: 23432438 PMCid: PMC3895342

5) Pomorska DK, Gach K, Janecka A. Immunomodulatory effects of endogenous and synthetic peptides activating opioid receptors. Mini reviews in medicinal chemistry. 2014;14(14):1148-55. DOI: 10.2174/1389557515666150101095237 PMid: 25553430

6) Schneider E, Ma X, Stratz T, Mueller W, Lorenz I, Seeling W. Immunomodulatory function of the 5 - HT3 receptor antagonist tropisetron. Scandinavian journal of rheumatology. 2004;33(sup119):34-40. DOI: 10.1080/03009740410007014

7) Eteraf-Oskouei T, Akbarzadeh-Atashkhosrow A, Maghsudi M, Najafi M. Effects of salbutamol on the inflammatory parameters and angiogenesis in the rat air pouch model of inflammation. Research in 
pharmaceutical sciences. 2017;12(5):364-72. DOI: 10.4103/1735-5362.213981 PMid: 28974974 PMCid: PMC5615866

8) Ghadrdan E, Najafi M, Mikaily Mirak S, Eteraf-Oskouei T. Inhibitory effects of oxytocin on the inflammatory parameters and vascular endothelial growth factor (VEGF) in the rat air pouch model of inflammation. Physiology and Pharmacology. 2016;20(1):48-56.

9) Maleki-Dizaji N, Eteraf-Oskouei T, Fakhrjou A, Maljaie SH, Garjani A. The effects of 5HT3 receptor antagonist granisetron on inflammatory parameters and angiogenesis in the air-pouch model of inflammation. International immunopharmacology. 2010;10(9):1010-6. DOI: 10.1016/j.intimp.2010.05.013 PMid: 20646986

10) Dutta R, Lunzer MM, Auger JL, Akgun E, Portoghese PS, Binstadt BA. A bivalent compound targeting CCR5 and the mu opioid receptor treats inflammatory arthritis pain in mice without inducing pharmacologic tolerance. Arthritis research \& therapy. 2018;20(1):154. DOI: 10.1186/s13075-018-1661-5 PMid: 30053832 PMCid: PMC6062996

11) Ninkovic J, Roy S. Role of the mu-opioid receptor in opioid modulation of immune function. Amino acids. 2013;45(1):9-24. DOI: 10.1007/s00726-011-1163-0 PMid: 22170499 PMCid: PMC3912755

12) Duarte DB, Vasko MR, Fehrenbacher JC. Models of Inflammation: Carrageenan Air Pouch. Current protocols in pharmacology. 2016;72:5.6.1-9. DOI: 10.1002/0471141755.ph0506s72 PMid: 26995549

13) Elshabrawy HA, Chen Z, Volin MV, Ravella S, Virupannavar S, Shahrara S. The pathogenic role of angiogenesis in rheumatoid arthritis. Angiogenesis. 2015;18(4):433-48. DOI: 10.1007/s10456-015-9477-2 PMid: 26198292 PMCid: PMC4879881

14) Clavel G, Valvason C, Yamaoka K, Lemeiter D, Laroche L, Boissier M-C, et al. Relationship between angiogenesis and inflammation in experimental arthritis. European cytokine network. 2006;17(3):202-10.

15) Patil KR, Mahajan UB, Unger BS, Goyal SN, Belemkar S, Surana SJ, et al. Animal Models of Inflammation for Screening of Anti-inflammatory Drugs: Implications for the Discovery and Development of Phytopharmaceuticals. International journal of molecular sciences. 2019;20(18):4367. DOI: 10.3390/ijms20184367 PMid: 31491986 PMCid: PMC6770891

16) Cornwell WD, Lewis MG, Fan X, Rappaport J, Rogers TJ. Effect of chronic morphine administration on circulating $\mathrm{T}$ cell population dynamics in rhesus macaques. J Neuroimmunol. 2013;265(1-2):43-50. DOI: 10.1016/j.jneuroim.2013.09.013 PMid: 24090653 PMCid: PMC3852163

17) Prossin AR, Zalcman SS, Heitzeg MM, Koch AE, Campbell PL, Phan KL, et al. Dynamic interactions between plasma IL-1 family cytokines and central endogenous opioid neurotransmitter function in humans. Neuropsychopharmacology : official publication of the American College of Neuropsychopharmacology. 2015;40(3):554-65. DOI: 10.1038/npp.2014.202 PMid: 25139063 PMCid: PMC4289943

18) Paulsson JM, Moshfegh A, Dadfar E, Held C, Jacobson SH, Lundahl J. In-vivo extravasation induces the expression of interleukin 1 receptor type 1 in human neutrophils. Clinical and experimental immunology. 2012;168(1):105-12. DOI: 10.1111/j.1365-2249.2011.04548.x PMid: 22385245 PMCid: PMC3390501

19) Abbas AK, Lichtman AH, Pillai S. Cellular and Molecular Immunology. 7 ed: Elsevier Health Sciences; 2012.

20) Chin PY, Dorian CL, Hutchinson MR, Olson DM, Rice KC, Moldenhauer LM, et al. Novel Toll-like receptor-4 antagonist (+)-naloxone protects mice from inflammation-induced preterm birth. Scientific reports. 2016;6:36112. DOI: 10.1038/srep36112 PMid: 27819333 PMCid: PMC5098167

21) Dinarello CA. A clinical perspective of IL-1beta as the gatekeeper of inflammation. European journal of immunology. 2011;41(5):1203-17. DOI: 10.1002/eji.201141550 PMid: 21523780

22) Morris CJ. Carrageenan-induced paw edema in the rat and mouse. Inflammation protocols. 2003:115-21. DOI: 10.1385/1-59259-374-7:115 PMid: 12769480

23) Liu T, Zhang M, Terry MH, Schroeder H, Wilson SM, Power GG, et al. Nitrite potentiates the vasodilatory signaling of S-nitrosothiols. Nitric oxide : biology and chemistry. 2018;75:60-9. DOI: 10.1016/j.niox.2018.01.011 PMid: 29428841 PMCid: PMC5861029

24) Liu B, GAO HM, WANG JY, JEOHN GH, Cooper CL, HONG JS. Role of nitric oxide in inflammation mediated neurodegeneration. Annals of the New York academy of sciences. 2002;962(1):318-31. DOI: 10.1111/j.1749-6632.2002.tb04077.x PMid: 12076984

25) Sato K, Komatsu N, Higashi N, Imai Y, Irimura T. Granulation tissue formation by nonspecific inflammatory agent occurs independently of macrophage galactose-type C-type lectin-1. Clinical Immunology. 2005;115(1):47-50. DOI: 10.1016/j.clim.2005.02.005 PMid: 15870020 
26) Smith JP, Stock H, Bingaman S, Mauger D, Rogosnitzky M, Zagon IS. Low-dose naltrexone therapy improves active Crohn's disease. The American journal of gastroenterology. 2007;102(4):820-8. DOI: 10.1111/j.1572-0241.2007.01045.x PMid: 17222320

27) Tani K, Shimizu T, Motoki Y, Sone S. Chemokines in synovial inflammation in rheumatoid arthritis: basic and clinical aspects. Modern rheumatology. 2002;12(2):93-9. DOI: 10.3109/s101650200017 PMid: 24383895

28) Burger E, Nishikaku A, Gameiro J, Francelin C, Camargo Z. Cytokines expressed in the granulomatous lesions in experimental Paracoccidioidomycosis: role in host protective immunity and as fungal virulence factor. J Clin Cell Immunol S. 2013;1:2.

29) Kapasi AA, Gibbons N, Mattana J, Singhal PC. Morphine stimulates mesangial cell TNF- $\alpha$ and nitrite production. Inflammation. 2000;24(5):463-76. DOI: 10.1023/A:1007016329300 PMid: 10921509

30) Pourpak Z, Ahmadiani A, Alebouyeh M. Involvement of interleukin-1beta in systemic morphine effects on paw oedema in a mouse model of acute inflammation. Scandinavian journal of immunology. 2004;59(3):273-7. DOI: 10.1111/j.0300-9475.2004.01396.x PMid: 15030578

31) Eteraf-Oskouei T, Mikaily Mirak S, Najafi M. Anti-Inflammatory and Anti-Angiogenesis Effects of Verapamil on Rat Air Pouch Inflammation Model. Advanced pharmaceutical bulletin. 2017;7(4):585-91. DOI: 10.15171/apb.2017.070 PMid: 29399548 PMCid: PMC5788213

32) Howdieshell TR, Webb, W. L., Sathyanarayana, McNeil, P. L. Inhibition of inducible nitric oxide synthase results in reductions in wound vascular endothelial growth factor expression, granulation tissue formation, and local perfusion. Surgery. 2003;133(5):528-37. DOI: 10.1067/msy.2003.128 PMid: 12773981

33) Salcedo X, Medina J, Sanz-Cameno P, Garcia-Buey L, Martin-Vilchez S, Moreno-Otero R. Review article: angiogenesis soluble factors as liver disease markers. Alimentary pharmacology \& therapeutics. 2005;22(1):23-30. DOI: 10.5483/BMBRep.2008.41.4.278 PMid: 18452647

34) Shibuya M. Vascular endothelial growth factor-dependent and-independent regulation of angiogenesis. BMB reports. 2008;41(4):278-86.

35) Mostafaie A, Mohammadi Motlagh H, Mansouri K. Angiogenesis and the models to study angiogenesis. Yakhteh Med J. 2010;11(4):374-81.

36) Croll SD, Ransohoff RM, Cai N, Zhang Q, Martin FJ, Wei T, et al. VEGF-mediated inflammation precedes angiogenesis in adult brain. Experimental neurology. 2004;187(2):388-402. DOI: 10.1016/j.expneurol.2004.02.010 PMid: 15144865

37) Świdrowska-Jaros J, Smolewska E. A fresh look at angiogenesis in juvenile idiopathic arthritis. CentralEuropean journal of immunology. 2018;43(3):325-30. DOI: 10.5114/ceji.2018.80052 PMid: 30863199 PMCid: PMC6410962

38) Lunger F, Vehmas AP, Furnrohr BG, Sopper S, Wildt L, Seeber B. Opiate receptor blockade on human granulosa cells inhibits VEGF release. Reproductive biomedicine online. 2016;32(3):316-22. DOI: 10.1016/j.rbmo.2015.12.006 PMid: 26803207

39) Singleton PA, Lingen MW, Fekete MJ, Garcia JG, Moss J. Methylnaltrexone inhibits opiate and VEGFinduced angiogenesis: role of receptor transactivation. Microvascular research. 2006;72(1-2):3-11. DOI: 10.1016/j.mvr.2006.04.004 PMid: 16820176

40) Chakrabarti S, Rizvi M, Morin K, Garg R, Freedman JE. The role of CD40L and VEGF in the modulation of angiogenesis and inflammation. Vascular pharmacology. 2010;53(3):130-7. doi: 10.1016/j.vph.2010.05.003 PMid: 20546942

41) Vujic V, Stanojevic S, Dimitrijevic M. Methionine-enkephalin stimulates hydrogen peroxide and nitric oxide production in rat peritoneal macrophages: interaction of mu, delta and kappa opioid receptors. Neuroimmunomodulation. 2004;11(6):392-403. doi: 10.1159/000080150 PMid: 15467355

42) Rotelli AE, Guardia T, Juárez AO, De la Rocha NE, Pelzer LE. Comparative study of flavonoids in experimental models of inflammation. Pharmacological research. 2003;48(6):601-6. doi: 10.1016/S10436618(03)00225-1

43) Kubota Y. Tumor angiogenesis and anti-angiogenic therapy. The Keio journal of medicine. 2012;61(2):4756. doi: 10.2302/kjm.61.47 PMid: 22760023

44) Zanardo V, Simbi A, Parotto M, Severino L, Carta R, Guerrini P, et al. Morphine-induced supraventricular tachycardia in near-term fetus. Italian journal of pediatrics. 2018;44(1):111. doi: 10.1186/s13052-0180570-1 PMid: 30249290 PMCid: PMC6154430 